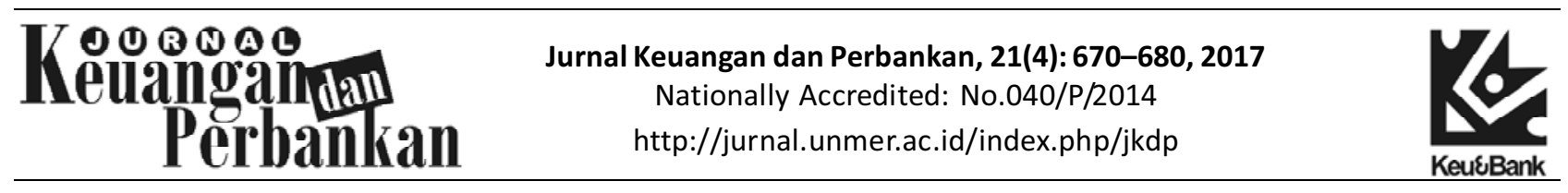

\title{
The Role of Corporate Governance and Risk Management on Banking Financial Performance in Indonesia
}

\author{
Mohamad Bastomi, Ubud Salim, Siti Aisjah \\ Department of Management Faculty of Economics and Business University of Brawijaya \\ Jl. MT.Haryono No.165 Malang, 65145, Indonesia
}

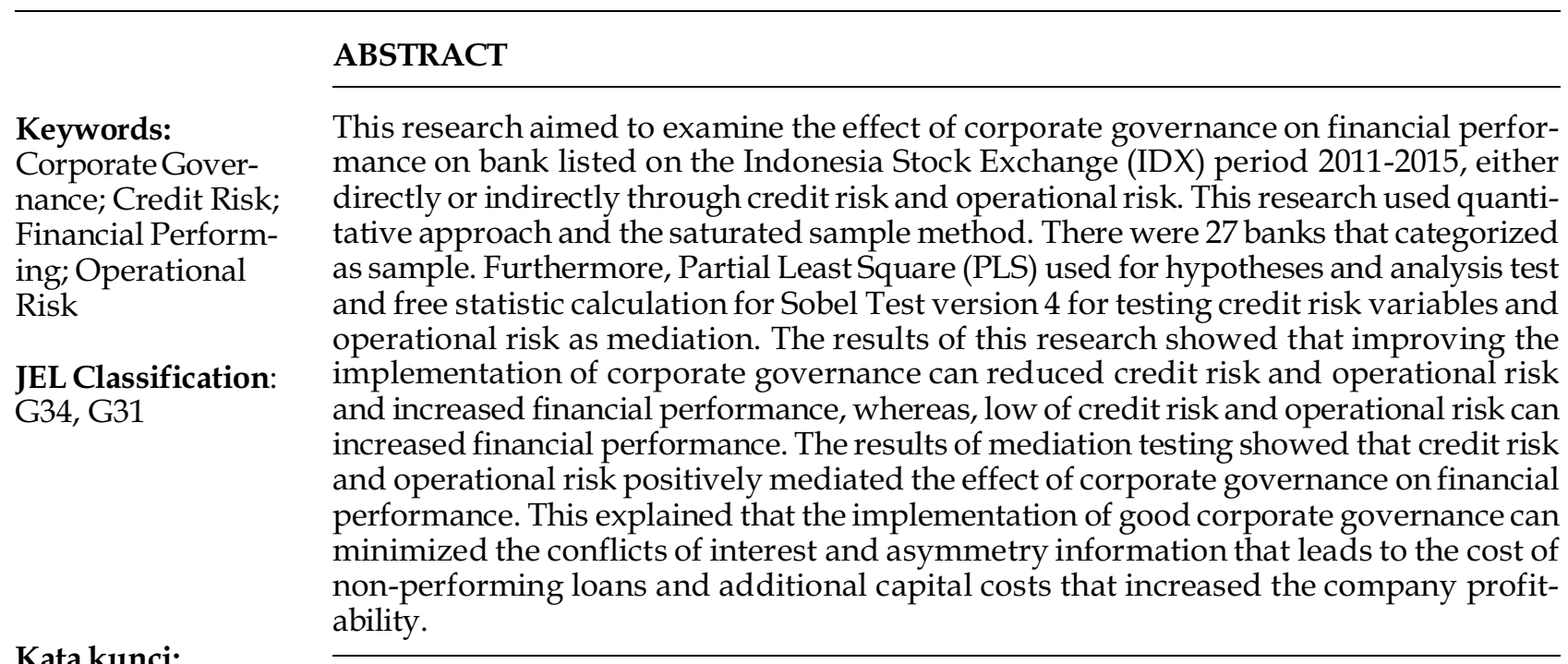

Tata Kelola

Perusahaan;

Risiko Kredit;

Kinerja Keuangan;

Risiko Operasional

\begin{abstract}
ABSTRAK
Penelitian ini bertujuan untuk menguji pengaruh antara tata kelola perusahaan terhadap kinerja keuangan pada perbankan yang terdaftar di Bursa Efek Indonesia (BEI) pada periode 2011-2015, baik secara langsung maupun tidak langsung melalui risiko kredit dan risiko operasional. Penelitian ini menggunakan pendekatan kuantitatif. Pengambilan sampel menggunakan metode sampel jenuh. Terdapat 27 perbankan yang memenuhi kategori sebagai sampel. Selanjutnya, Partial Least Square (PLS) digunakan untuk analisis dan pengujian hipotesis dan software Free Statistic Calculation for Sobel Test versi 4 untuk pengujian variabel risiko kredit dan risiko operasional sebagai mediasi. Hasil penelitian menunjukkan bahwa perbaikan pelaksanaan tata kelola perusahaan dapat menurunkan risiko kredit dan risiko operasional serta meningkatkan kinerja keuangan, sedangkan rendahnya risiko kredit dan risiko operasional dapat meningkatkan kinerja keuangan. Hasil pengujian mediasi menunjukkan bahwa risiko kredit dan risiko operasional memediasi secara positifpengaruh antara tata kelola perusahaan terhadap kinerja keuangan. Hal ini menjelaskan bahwa pelaksanaan tata kelola perusahaan yang baik dapat meminimalkan benturan kepentingan dan asimetri informasi yang menyebabkan timbulnya biaya cadangan penghapusan kredit macet dan biaya modal tambahan sehingga meningkatkan profitabilitas perusahaan.
\end{abstract}

Corresponding Author

Mohamad Bastomi: Tel.+62 341 551396; Fax.+62 341553834.

E-mail: mohamadbastomy@yahoo.com

ISSN:2443-2687 (Online) ISSN:1410-8089 (Print) 


\section{The Role of Corporate Governance and Risk Management on Banking Financial Performance in Indonesia}

Banking as an intermediary institution that using the principle of trust so that it is very vulnerable to negative issues related to performance or potential fraud as an agent of trust. The bank must maintain the trust given by its customers to manage their funds safely and profitably. The banking industry as a high regulated industry receives special attention from the government over other industries because of its vital role. It can be concluded that the necessary for banking performance assessment must be fulfilled properly and accurately.

The poor stability of the banking industry, causing the economy country into a multidimensional crisis. The low quality of corporate governance and corporate risk management in Indonesia is believed to be the downfall of Indonesian companies in the 1997-1998 monetary crises, particularly the banking industry. Strategic measures taken by Bank Indonesia (BI) as the central bank in efforts to rebuild the Indonesian economy through the enactment of Bank Indonesia Regulation Number 13/1/PBI/2011 about on the rating of the stability of commercial banks in which banks are required to carry out an assessment that covers aspects of risk, corporate governance, profitability, and capital. Implementation of corporate governance is considered to improve the image of banking. Protect the stakeholder's interests and improve compliance with prevailing laws and regulations, and common ethics in the banking industry in order to represent a healthy banking system.

The fundamental problem of emergence of interest conflict that potentially leads agency cost, so that will reduce the value of company (Hanggraeni, 2014). This implies that there is an opportunity for the forces exploitation which resulted in disruption of an enterprise system. Moreover, it is not surprising that management is out of control, will tend to manage the company in order to maximize the prosperity of its managers more than the welfare of shareholders.

Corporate governance in financial institutions, especially banks, is unique when compared to non-bank financial institutions. The behavior of managers and bank owners became a major factor that needs attention in the implementation of corporate governance. The agency theory that is often used in the application of corporate governance is not fully usable in the banking industry particularly. The banking industry has a higher complexity than any other industry so the possibility of emerging information asymmetry is also high. The impact that occurs due to high information asymmetry can make difficult for other parties to supervise the performance of bank governance. Meanwhile, management control will be easier with the dominant shareholder, but it becomes an opportunity for the emergence of misconduct, fraud, or moral hazard to the management of public funds to meet personal or group interests.

Banking characteristics has own uniqueness when compared with other financial companies or non-financial companies so that the corporate governance implementation is also unique. It can be seen from banking assets that on average consist of loans that mostly have long-term character, while the liability consisting of savings and deposits is a short-term character. This is what encourages being more cautious in managing their assets in order to avoid mismatch between liabilities and assets. Management risk implementation can control risk more better, companies can further explore and exploit existing opportunities, improve relationships with stakeholders, can be enhance the company's reputation, and also protect the directors and other officials in managing the company (Susilo \& Kaho, 2010).

Unstable economic environment and tight competition, causing companies to be vulnerable to risks that threaten the performance achievement that has been targeted because high performance achievement has a high risk (Badriyah, Sari, \& 


\section{Jurnal Keuangan dan Perbankan | PERBANKAN}

Vol. 21, No. 4, Oktober 2017: 670-680

Basri 2015). Profile risk management on Indonesian banking management risk implementation process is not easy to do. Although it has been regulated, in fact many banks were not disclosure yet about financial risk. It can be seen that some companies even integrate the risk management function with internal audit, even found a company that incorporates risk management with a finance director or with operations director. Hanggraeni (2014) concludes that the director's board and commissioners have not realized the importance of implementing integrated risk management, or even knowing but are reluctant to implement due to certain objectives.

The low commitment to the principles corporate governance implementation is also closely related to the level of risk faced by banks. Banks with good information systems can also be faced with a failure if the principles of governance are not working properly. Characteristics of good corporate governance and risk management structures are able to strengthen company performance during crisis (Aebi, Sabato, \& Schmid, 2012). It means reflected reflects that the risks and corporate governance implementation are closely linked.

The global financial crisis experience has prompted the necessary for increased effectiveness of risk management and corporate governance implementation. Good corporate governance does not always have a positive impact on the company's performance immediately (Hanggraeni, 2014). The entrepreneurs appraise good corporate governance limited by regulations that do not have a direct impact on financial performance as in marketing activities (Purwani, 2010). A contradictory thing, where the implementation of corporate governance is believed to be important in achieving sustainable corporate objectives, but on the other hand many business actors are reluctant to apply it seriously by reason of a less significant impact on financial performance.
This research was conducted by integrating a broader research model, through the previous studies models development. Corporate governance measurement uses an index developed by the Organization of Economic Cooperation and Development (OECD), as G20 leaders have agreed as a global standard on corporate governance. Risk management in this study focused on the crucial risks namely credit risk and operational risk, which operational risk is often misidentified as credit risk, or vice versa. Considering the importance of assessing the level of banks financial performance, so that, the application of market-based valuations of financial performance is considered more objective due to the reduced control of corporate managers.

\section{HYPOTHESES DEVELOPMENT}

According to the OECD in Aldridge \& Sutojo (2005), corporate governance is defined as a set of relationships between the company's management, board and shareholders, and others who have an interest in the company. The following principles of corporate governance have been referred to by countries in the world including Indonesia, since being introduced by OECD. These are arranged universally so that they can apply to all countries or companies and are harmonized with the legal system, rules, or values prevailing in their respective countries. The main principles of governance offered by OECD, namely fairness, disclosure/ transparency, accountability, responsibility, and independency.

OECD thought the corporate governance as a system which a company or business entity is directed and supervised. Scores Rating systems or corporate governance indexes can provide information on how well companies are implementing corporate governance as they can represent the level of implementation of comprehensive corpo- 


\section{The Role of Corporate Governance and Risk Management on Banking Financial Performance in Indonesia}

Mohamad Bastomi, Ubud Salim, Siti A

rate governance. The Corporate Governance Perception Index (CGPI) method developed by the OECD based on International Standard Code on Corporate Governance following 5 areas of study, shareholder rights, equal treatment of shareholders, stakeholder roles, disclosure and transparency, and board responsibilities and commissioners. The formula of CGPI in this research as follows:

CGPI $=\frac{\text { Number of items published }}{\text { Total OECD indicator items }}($ Siagian, Siregar, \& Rahadian, 2013)

Previous studies related to the corporate governance have been conducted in a variety models, which point out pros and cons of research findings, especially in the effect on financial performance. For example in research conducted by Hoque, Islam, \& Ahmed (2012), Kusmayadi (2012) and Outa \& Waweru (2016), found that corporate governance had a positive effect on financial performance. This is contrast to the research by Aebi, Sabato, \& Schmid (2012), Poudel (2012), and Hassan \& Halbouni (2013), which stated that corporate governance practiced have no significant effect on financial performance. Furthermore, related to the effect of corporate governance on credit risk, Oliveira et al. (2014) and Permatasari \& Novitasary (2014), found that corporate governance had a significant effect on risk management. This finding is contrast to the Rachdi, Trabelsi, \& Trad (2013) who found that corporate governance has no effect on credit risk. Other researchers examining the corporate governance effect on operational risks, such as Chernobai, Jorion, \& Yu (2011) and Liu \& Cortes (2015) found that corporate governance had a significant effect on operational risk. The findings contradict with Kallenberg (2009) that the enterprise risk management approach is preferred than management operational risk.

$\mathrm{H}_{1}$ : the corporate governance effect on financial performance

$\mathrm{H}_{2}$ : the corporate governance effect on credit risk
$\mathrm{H}_{3}$ : the corporate governance effect on operational risk

Credit risk is a bank continuing risk to distribute funds in the form of loans to customers (Attar, Islahuddin, \& Shabri, 2014). According to Indonesian Central Bank Regulation Number 13/ 1/PBI/ 2011 about Commercial Bank Rating Assessment, is the higher nonperforming loan (NPL) value above 5 percent, the bank is unsoundness. If the NPL value is high, it will make decrease profit received by bank. NPL reflected credit risk, if NPL is lower, credit risk lower too. This ratio also illustrates the bank's ability to meet its liquidity by holding its loan withdrawal to meet other credit demand. If the NPL level is high it will affect the soundness of the bank, which will lead to decrease in bank soundness.

The formula of credit risk in this research is as follows (SE BI 13/24/DPNP/2011):

$\mathrm{NPL}=\frac{\text { Bad Loans }}{\text { Total Loans }} \times 100 \%$

Empirically, research by Arif \& Anees (2012), Poudel (2012), and Attar, Islahuddin, \& Shabri (2014), found that credit risk had effect to bank financial performance. That findings are contradictive with research by Haryati \& Kristijadi (2014) stated that profile risk approach is was not effect to financial performance. Its support by Karim \& Alam (2013) stated that credit risk is not effect to Tobin's Q.

$\mathrm{H}_{4}$ : the credit risk effect on financial performance

Operational risk is risk that causing by internal process malfunction, human error, system failure, or external problem which effect to bank operational (Setiawaty, 2016). Based on SEBI Number 6/23/2004, operational expenses maximum value to operational income (BOPO) is 94 percent. If bank has $\mathrm{BOPO}$ more than regulation that de- 


\section{Jurnal Keuangan dan Perbankan | PERBANKAN}

Vol. 21, No. 4, Oktober 2017: 670-680

termine, so that the bank categorized to inefficient, because too high $\mathrm{BOPO}$ it means increasing operational cost high than increasing operational income, so that less profit received. The formula operational risk in this research as follows (SE BI 13/24/DPNP/2011):

$\mathrm{BOPO}=\frac{\text { Operational Expenses }}{\text { Operational Income }} \times 100 \%$

Empirically, research by Chernobai, Jorion, \& Yu (2011) and Liu \& Cortes (2015) found that good corporate governance significant effect to operational risk. That finding contradictive with Kallenberg (2009) that enterprise risk management approach preferably than operational risk management.

$\mathrm{H}_{5}$ : the operational risk effect on financial performance

Financial performance is a factor that shows organization affectivity and efficiency in terms to achieve the goal (Purwani, 2010). Financial performance assessment considers cumulative financial impact related to published financial data which made generally financial accounting principal. Financial performance can be seen by analysis instruments. Financial performance analysis as a critically assessment process to data review, calculate, measure, interpreted, and give solution to corporate financial in certain period. The formula financial performance in this research as follow (Reddy, Locke, \& Scrimgeour, 2010):

Tobin's $\mathrm{Q}=\frac{\text { MVE }+\mathrm{L} / \mathrm{T} \text { Debt }+ \text { Net S } / \text { T Debt }}{\text { Total Assets }}$

Empirically, related to credit risk, research by Roziq \& Danurwenda (2012), Oliveira et al. (2014), and Permatasari \& Novitasary (2014) that corporate governance had influence to risk management. Different result found by Rachdi, Trabelsi, \& Trad (2013) and Rachmadan \& Harto
(2013) that corporate governance indicator which not influenced to credit risk. In the other hand, Karim \& Alam (2013) and Haryati \& Kristijadi (2014) found that risk profile has not significant influenced and positive to financial performance. On the corporate governance indirectly effect to corporate performance with credit risk as mediation variable, Joeswanto \& Malelak (2015) and Setiawaty (2016) found that risk management mediated the influenced between good corporate governance to bank performance. Furthermore, Roziq \& Danurwenda (2012) found that business risk is not mediation variable from the corporate governance influence to financial performance.

Empirically, related to the operational risk by Chernobai, Jorion, \& Yu (2011) and Liu \& Cortes (2015), showed that shock absorption capability, governance, and risk management significant positive influenced to operational efficiency. Besides, research by Gillet, Hübner, \& Plunus (2010), Ongore \& Kusa (2013), and Attar, Islahuddin, \& Shabri (2014), showed that operational risk influenced to financial performance. Different finding stated by Rasid, Rahman, \& Ismail (2011), Eken \& Kale (2013), and Haryati \& Kristijadi (2014) showed that risk profile has no significant influence to financial performance. On the corporate governance indirectly effect to corporate performance with operational risk as mediation variable, Permatasari \& Novitasary (2014) and Badriyah, Sari, \& Basri (2015) found that risk management mediated the influence between corporate governance to capital and banking performance. That finding was contradictive with Roziq \& Danurwenda (2012) found that business risk is not mediation variable from the corporate governance influenced to financial performance.

$\mathrm{H}_{6}$ : the corporate governance effect on financial performance through credit risk

$\mathrm{H}_{7}$ : the corporate governance effect on financial performance through operational risk 


\section{The Role of Corporate Governance and Risk Management on Banking Financial Performance in Indonesia}

Mohamad Bastomi, Ubud Salim, Siti A

\section{METHODS}

Type of this research is explanatory through quantitative approach. This research held on banking which listing on Indonesia Stock Exchange (IDX) in 5 periods (2011-2015). In this research used non probability approach sampling with saturation sampling method, means all the populations, 27 corporates used as research sample. Data collection in this research used documentation method. The hypothesis test and analysis through Partial Least Square (PLS) is used for mediation variable test through free statistic calculation for Sobel test software version 4 .

\section{RESULTS}

In corporate governance variables obtained an average 0.777 with a standard deviation 0.808 . In general, corporate governance mechanisms implemented in banks is respectable and very good categorized by SEBI Number 13/24/DPNP/2011, under 1.5 with average 62 items which published for total 80 items based OECD principles.

On the credit risk variable obtained an average is 2.516 with a standard deviation is 2.064 . It means that credit risk level on the bank above 2 percent and below 5 percent are quite good categorized soundness by SEBI Number 6/23/DPNP / 2011.

On the operational risk variable obtained an average is 78.858 with a standard deviation is 18.854. It means that Bank BOPO level under 94 percent is quite good with categorized very well by SEBI Number 6/23/DPNP/2011.

On the financial performance variable obtained an average 0.118 with standard deviation is 0.287 . Companies that have a value of Tobin's $Q$ $<1$ showed that the stock is undervalued.

Linearity test results through curve test showed the relationship between independent variables and dependent variables are linier which shown by probability result of each smaller relationship from alpha 5 percent $(0.05)$ so the linearity assumption be fulfilled.

The next stage is hypothesis test to examine dependent and independent variables causality which develop on model. T-statistics used to determine the significant or insignificant and accepted or rejected. If T-statistics more than t-table 1.96, the hypothesis accepted and vice versa. Based on data analysis, obtained by path coefficient shown in Table 1.

Table 1 show that the influence between corporate governance $(X)$ and credit risk $\left(Z_{1}\right)$ has value -0.382 with T-statistics 7.560 . The relationship corporate governance $(X)$ and operational risk $\left(Z_{2}\right)$ has value -0.414 with T-statistics 5.627 , whereas credit risk $\left(Z_{1}\right)$ to financial performance -0.133 with T-statistics 2.065, operational risk $\left(Z_{2}\right)$ to financial performance -0.241 with t-statistics 4.146 . While the relationship corporate governance $(X)$ to financial performance (Y) 0.502 with T-statistics 12.916. Meanwhile, indirectly corporate governance relationship to financial performance through credit

Tabel 1. Testing Influence between Variables by Path Analysis

\begin{tabular}{clcccc}
\hline Hypotheses & \multicolumn{1}{c}{ Effects } & Coefficient & S.E. & t- Statistics & Information \\
\hline 1 & $\mathrm{X} \rightarrow \mathrm{Y}$ & 0.351 & 0.052 & 6.649 & Significant \\
2 & $\mathrm{X} \rightarrow-\mathrm{Z}_{1}$ & -0.321 & 0.050 & 7.560 & Significant \\
3 & $\mathrm{X} \rightarrow \mathrm{Z}_{2}$ & -0.414 & 0.073 & 5.627 & Significant \\
4 & $\mathrm{Z}_{1} \rightarrow \mathrm{Y}$ & -0.133 & 0.064 & 2.065 & Significant \\
5 & $\mathrm{Z}_{2} \rightarrow \mathrm{Y}$ & -0.241 & 0.058 & 4.146 & Significant \\
6 & $\mathrm{X} \rightarrow \mathrm{Z}_{1} \rightarrow \mathrm{Y}$ & 0.051 & 0.030 & 1.976 & Significant \\
7 & $\mathrm{X} \rightarrow \mathrm{Z}_{2} \rightarrow \mathrm{Y}$ & 0.100 & 0.026 & 3.305 & Significant
\end{tabular}


risk 0.100 and T-statistics 3.305. Indirectly corporate governance relationship to financial performance through operational risk 0.051 and T-statistics 1.976. All the each variable correlation value have negative beta coefficient, except the relationship between corporate governance and financial performance with T-statistics more than 1.960 where the relationship and each negative variable effect, except the relationship between corporate governance and financial performance significant. Therefore, it can be concluded that all hypotheses are accepted as expected.

\section{DISCUSSION}

\section{The Effect of Corporate Governance on Financial Performance}

Based on data analysis known that corporate governance has a significant positive effect on financial performance. This finding showed that good corporate governance can be seen from policies, procedure, instruction, and structure that is executed by corporate not made overlaps which confusing the employers. Conducive work environmental raise effective operational activity, minimum collision, and supervisory activity which synergic with strategic priority so that minimize the scandal, chaos, and internal corruption. The implementation of good corporate governance will make investors give a positive response to financial performance and increase the market value of the company.

This finding supported previous study by Darwis (2009), Kusmayadi (2012), Kumaat (2013), and Outa \& Waweru (2016) which showed that corporate governance had positive significant effect to financial performance. That result supported by Hoque, Islam, \& Ahmed (2012) which found that corporate governance had effect to bank performance through Return of Equity (ROE), Return of Asset (ROA), and Tobin's Q.

\section{The Effect of Corporate Governance on Credit Risk}

The research finding showed that corporate governance had negative and significant effect on credit risk. If large credit number which distributed by bank, so, will more large potential risk default. In addition to do not obtaining interest income, non-performing loans have caused banks to issue additional funds to handle it, even the loan principal that does not return make the bank must spend the cost of loss reserves for the elimination of bad debts due to default debtor. The assessment related to the risk is one of the points in public disclosure of banking information, so the high of corporate governance value explains that credit risk management is well executed so that non-performing loans are small. Besides that, top management and board related to the corporate governance implementation made the company more selective on credit distribution to decrease the problem loans.

These findings supported the previous research by Permatasari \& Novitasary (2014) which showed that corporate governance had the effect on risk management. Those results emphasized by Oliveira et al. (2014) which explain that bank give the loans to companies that adopt the good corporate governance, while the corporate governance application is considered highly relevant in the process of credit risk assessment.

\section{The Effect of Good Corporate Governance on Operational Risk}

The results of this study showed that corporate governance has a negative and significant impact on operational risk. Operational risk is embedded in every bank activity, especially related to the various problems that can result from bank process failure. Operational risk can have a 


\section{The Role of Corporate Governance and Risk Management on Banking Financial Performance in Indonesia Mohamad Bastomi, Ubud Salim, Siti A}

direct impact on monetary losses in the form of additional costs to indemnify and non-moteray losses that are the loss/ decrease in opportunity banks earn revenue. The existence of corporate governance makes investors feel safe because it lowers the cost of capital that must be issued by the company. Due to the low risk that must be borne by all parties to the company in the form of low cost production and vice versa. The results of this study are relevant to previous research conducted by Chernobai, Jorion, \& Yu (2011) which shows corporate governance has significant effect on operational risk. The results are supported by Liu \& Cortes (2015) which show that governance has a significant positive effect on operational efficiency.

\section{The Effect of Credit Risk on Financial Performance}

From this research obtained that credit risk has a negative effect on financial performance. Operational budget preparation can be better if the amount is not too large so it can help in achieving company goals to increase the profit. The budget realization achievement in accordance with that has been compiled and determined, indicating that the management of risks is good. The high operational risk indicates that the bank has not been able to utilize its owned resources or has not been able to implement its business efficiently. Investors judge the good corporate performance if the company has low capital costs that encourage the investors to invest. When many investors interested to invest on company will increase investment demand that will increase the company's profitability growth.

The results of this study are relevant to previous research conducted by Attar, Islahuddin, \& Shabri (2014) which found that operational risks simultaneously affect the financial performance of banks. Gillet, Hübner, \& Plunus (2010) explains that the loss of market value is due to the announcement of the amount of operational losses, so that substantial savings can be achieved through active management techniques (Chapelle et al., 2008).

\section{The Effect of Corporate Governance on Financial Performance through Credit Risk}

In the last stage, to confirm the role of credit risk mediation between corporate governance and financial performance, researchers used the Free Statistic Calculation Software for Sobel Test version 4 . The results are as expected, credit risk may mediate the effect of corporate governance on financial performance. The result shows that credit risk is a predictor of financial performance condition. Managers can maximize profitability effectively through credit risk so as to minimize the number of problem loans that can reduce profits in order to achieve corporate goals. In other words, the lower the corporate credit risk level, will higher the financial performance in the company's operations.

The results of this study are relevant to previous research conducted by Arif \& Anees (2012), Poudel (2012), Roziq \& Danurwenda (2012), Oliveira et al. (2014), Permatasari \& Novitasary (2014), Badriyah, Sari, \& Basri (2015), Joeswanto \& Malelak (2015), and Setiawaty (2016), which has found a relationship and effect between corporate governance and financial performance, either directly or indirectly.

\section{The Effect of Corporate Governance with Financial Performance through Operational Risk}

The results of this study indicate that corporate governance has a significant and positive impact on financial performance through operational risk. The results indicate that operational risk is a predictor of financial performance condi- 


\section{Jurnal Keuangan dan Perbankan | PERBANKAN}

Vol. 21, No. 4, Oktober 2017: 670-680

tion. Managers can maximize profitability efficiently through operational risk so as to minimize the amount of operational costs that can reduce profits in order to achieve corporate goals. In other words, the lower the operational risk levels of the company, the higher the financial performance in the company's operations.

The results of this study are in accordance with previous studies conducted by Chapelle et al. (2008), Gillet, Hübner, \& Plunus (2010), Chernobai, Jorion, \& Yu (2011), Roziq \& Danurwenda (2012), Ongore \& Kusa (2013), Attar, Islahuddin, \& Shabri (2014), Badriyah, Sari, \& Basri (2015), and Liu \& Cortes (2015), who have found a relationship and effect between corporate governance on financial performance, either directly or indirectly.

\section{CONCLUSION AND SUGGESTIONS}

\section{Conclusion}

The results of this study indicate that corporate governance has effect on credit risk, operational risk and financial performance. Good corporate governance implementation makes credit risk and operational risks low and increase financial performance. While the low credit risk and operational risk make financial performance increased. Credit risk management and operational risk indirectly able to support the corporate governance implementation and financial performance. This reflects investors' assumptions to companies that implement good governance are able to improve their financial performance due to minimum risk faced makes the capital cost, additional costs for the reserve cost.

\section{Suggestions}

Researchers noted there is limitedness in this study. First, other unpublished information in the company's annual report can't be included in the OECD index calculation. Secondly, the results of this study are not representative enough to represent all publicly traded companies in Indonesia. Therefore, further research can reexamine this research model in different research contexts and perspectives and use different measurement models. For the bank, it should be able to improve corporate governance performance to reduce credit risk and operational risk so that financial performance is better. The results of this study contribute to the importance of corporate governance in the banking sector in reducing the banks risk and can increase bank financial performance.

\section{REFERENCES}

Aebi, V., Sabato, G., \& Schmid, M. (2012). Risk management, corporate governance, and bank performance in the financial crisis. Journal of Banking $\mathcal{E}$ Finance, 36(12), 3213-3226.

Aldrige, E. J., \& Sutojo, S. (2005). Good Corporate Governance. Jakarta: PT. Damar Media Pustaka.

Arif, A., \& Anees, A. N. (2012). Liquidity risk and performance of banking system. Journal of Financial Regulation and Compliance, 20(2), 182-195.

Attar, D., Islahuddin, \& Shabri, M. (2014). Pengaruh penerapan manajemen risiko terhadap kinerja keuangan perbankan yang terdaftar di Bursa Efek Indonesia. Jurnal Akuntansi Pascasarjana Universitas Syiah Kuala, 3(1), 10-20.

Badriyah, N., Sari, R. N., \& Basri, Y. M. (2015). The effect corporate governance and firm characteristics on firm performance and risk management as an intervening variable. Procedia Economics and Finance, $31,868-875$.

Bank Indonesia. (2004). Surat Edaran Bank Indonesia Nomor 6/23/DPNP perihal sistem penilaian tingkat kesehatan bank.

Bank Indonesia. (2011). Peraturan Bank Indonesia Nomor 13/1/PBI/2011 tentang penilaian tingkat kesehatan bank umum.

Bank Indonesia. (2011). Peraturan Bank Indonesia Nomor 13/24/DPNP perihal sistem penilaian tingkat kesehatan bank umum. 


\title{
The Role of Corporate Governance and Risk Management on Banking Financial Performance in Indonesia
}

\author{
Mohamad Bastomi, Ubud Salim, Siti A
}

Chapelle, A., Crama, Y., Hubner, G., Peters, J. P. (2008). Practical methods for measuring and managing operational risk in the financial sector: A clinical study. Journal of Banking E Finance, 32, 1049-1061.

Chernobai, A., Jorion, P., \& Yu, F. (2011). The determinants of operational risk in U.S. financial institutions. Journal of Financial and Quantitative Analysis, 46(6), 1683-1725.

Darwis, H. (2009). Corporate governance terhadap kinerja perusahaan. Jurnal Keuangan dan Perbankan, 13(3), $418-430$

Eken, M. H., \& Kale, S. (2014). Evaluating the efficiency of Turkish banks: A risk and profitability approach. The Business and Economics Research Journal, 6(1), 53-68.

Gillet, R., Hübner, G., \& Plunus, S. (2010). Operational risk and reputation in the financial industry. Journal of Banking $\mathcal{E}$ Finance, 34, 224-235.

Hanggraeni, D. (2014). Manajemen risiko perusahaan (enterprise risk management) dan good corporate governance. Jakarta: UI-Press.

Haryati, S., \& Kristijadi, E. (2014). The effect of GCG implementation and risk profile on financial performance at go-public national commercial banks. Journal of Indonesian Economy and Business, 29(3), 237-250.

Hassan, M. K., \& Halbouni, S. S. (2013). Corporate governance, economic turbulence, and financial performance of UAE listed firms. Studies in Economics and Finance, 30(2), 118-138.

Hoque, M. Z., Islam, M. R., \& Ahmed, H. (2012). Corporate governance and bank performance: The case of Bangladesh. SSRN.

Joeswanto, D. A., \& Malelak, M. I. (2015). Analisis efek mekanisme good corporate governance terhadap manajemen risiko dalam pembentukan kinerja perbankan. Finesta, 3(1), 1-6.

Kallenberg, K. (2009). Operational risk management in Swedish industry: Emergence of a new risk paradigm? Risk Management, 11(2), 90-110.

Karim, R. A., \& Alam, T. (2013). An evaluation of financial performance of private commercial banks in Bangladesh: Ratio analysis. Journal of Business Studies Quarterly, 5(2), 66-77.
Kusmayadi, D. (2012). Determinasi audit internal dalam mewujudkan Good Corporate Governance serta implikasinya pada kinerja bank. Jurnal Keuangan dan Perbankan, 16(1), 147-156.

Liu, H. H. \& Cortes, M. (2015). An assessment of the efficiency of operational risk management in Taiwan's banking industry: An application of the stochastic frontier approach. Journal of Operational Risk, 10(1), 127-156.

Kumaat, L. C. (2011). Corporate Governance dan struktur kepemilikan terhadap manajemen laba dan kinerja keuangan. Jurnal Keuangan dan Perbankan, 17(1), $11-20$

Oliveira, M. C., Barbosa, F. L. S., Marcon, R., Alencar, R. C. D., Matos, F. (2014). Relevance of corporate governance to credit risk analysis in financial institutions. Universidade Federal Do Paraná, 6(3), 57-73.

Ongore, V. O., \& Kusa, G. B. (2013). Determinants of financial performance of commercial banks in Kenya. International Journal of Economics and Financial, 3(1), 237-252.

Outa, E. R., \& Waweru, N. M. (2016). Corporate governance guidelines compliance and firm inancial performance Kenya listed companies. Managerial Auditing Journal, 31(8/9), 891-914.

Permatasari, I., \& Novitasary, R. (2014). Pengaruh implementasi good corporate governance terhadap permodalan dan kinerja perbankan di Indonesia: Manajemen risiko sebagai variabel intervening. Jurnal Ekonomi Kuantitatif Terapan, 7(1), 1-82.

Poudel, R. P. S. (2012). The impact of credit risk management on financial performance of commercial banks in Nepal. International Journal of Arts and Commerce, 1(5), 9-15.

Purwani, T. (2010). Pengaruh good corporate governance terhadap kinerja perusahaan. Majalah Ilmiah Informatika, 1(2), 47-60.

Rachdi, H., Trabelsi, M. A., \& Trad, N. (2013). Banking governance and risk: The case of Tunisian conventional banks. Review of Economic PerspectivesNárodohospodáøský Obzor, 13(4), 195-206.

Rachmadan, A., \& Harto, P. (2013). Pengaruh mekanisme corporate governance terhadap risiko perbankan. Diponegoro Journal of Accounting, 2(3), 1-11. 


\section{Jurnal Keuangan dan Perbankan | PERBANKAN}

Vol. 21, No. 4, Oktober 2017: 670-680

Rasid, S. Z. A., Rahman, A. R. A., \& Ismail, W. K. W. (2011). Management accounting and risk management in Malaysian financial institutions: An exploratory study. Managerial Auditing Journal, 26(7), 566-585.

Ratih, S. (2011). Pengaruh Good Corporate Governance terhadap nilai perusahaan dengan kinerja keuangan sebagai variabel intervening pada perusahaan peraih The Indonesian Most Trusted Company-CGPI. Jurnal Kewirausahaan, 5(2), 19784724.

Reddy, K., Locke, S., \& Scrimgeour, F. (2010). The efficacy of principle-based corporate governance practices and firm financial performance: An empirical investigation. International Journal of Managerial Finance, 6(3), 190-219.
Roziq, A., \& Danurwenda, H. N. (2012). Pengaruh Good Corporate Governance terhadap Corporate Social Responsibility melalui Risiko Bisnis dan Kinerja Keuangan pada Bank Umum Syariah di Indonesia. Jurnal Akuntansi, 10(1), 90-109.

Setiawaty, A. (2016). Pengaruh mekanisme good corporate governance terhadap kinerja perbankan dengan manajemen risiko sebagai variabel intervening. Jurnal Ekonomi dan Manajemen, 13(1), 1324.

Siagian, F., Siregar, S. V., \& Rahadian, Y. (2013). Corporate governance, reporting quality, and firm value: Evidence from Indonesia. Journal of Accounting in Emerging Economies, 3(1): 4-20.

Susilo, L. J., \& Kaho, V. R. (2010). Manajemen Risiko Berbasis ISO 31000. Jakarta: PPM Manajemen. 